\title{
Reduced Insulin Binding to Hepatic Plasma Membranes in D-Galactosamine-Treated Rats
}

\author{
W. Bachmann, M. Haslbeck, I. Böttger, K. D. Hepp, and H. Mehnert \\ Forschergruppe Diabetes and III. Medizinische Abteilung, Stadtkrankenhaus Schwabing, München, FRG
}

Summary. Six to $12 \mathrm{~h}$ after IP injection of $400 \mathrm{mg} / \mathrm{kg}$ of $\mathrm{D}$-galactosamine in rats a 5 -fold increase in plasma insulin was observed. In addition, impaired glucose assimilation was present after an IV load in spite of unchanged fasting glucose levels. In streptozotocin-diabetic rats $(100 \mathrm{mg} / \mathrm{kg} \mathrm{IV})$ plasma insulin remained diminished $12 \mathrm{~h}$ after induction of Dgalactosamine hepatitis. Under identical conditions of preparation and incubation, the liver plasma membranes of $\mathrm{D}$-galactosamine-treated rats, in both normal and diabetic states, bound only $40-60 \%$ as much insulin per mg of membrane protein as those of the control rats. Scatchard analysis suggested that this was due to a decrease in the number of receptor sites in the membranes of the D-galactosamine-injected rats. No difference in the insulin degrading capacity and in insulin-receptor dissociation of the plasma membranes between control and D-galactosaminetreated groups was found. These data suggest that a reduction in the number of hepatic insulin receptors in galactosamine hepatitis can lead to insulin resistance and hyperinsulinaemia.

Key words: Galactosamine hepatitis, hyperinsulinaemia, insulin resistance, liver plasma membranes, insulin binding.

Studies on the obese-hyperinsulinaemic syndrome in animals $[1,2]$ and patients $[3,4]$, and on insulindeficient animals [5, 6] and humans [7], showed an inverse relationship between plasma insulin concentration and the number of specific insulin receptors of target tissues: a high plasma insulin level reduced the insulin binding capacity of the target cells and vice versa. Under these conditions a change in the plasma insulin concentration is thought to be the primary event $[1,2,8]$. On the other hand, a primary alteration at the insulin receptor site has not yet been reported.

In animals, IP-injected D-galactosamine induces acute hepatitis which is biochemically and morphologically similar to human virus hepatitis [9]. As early as 3 to $6 \mathrm{~h}$ after the injection of D-galactosamine, distinct alterations of the protein and phospholipid metabolism of the liver plasma membrane [10] and impairment of hepatic glycoprotein metabolism have been observed [11]. In addition, $24 \mathrm{~h}$ after galactosamine injection hyperinsulinaemia was found [12]. It seemed likely that along with these metabolic changes alterations of the hepatic insulin receptor, a glycoprotein [13-15], could occur. This would allow the possibility of inducing an insulin receptor defect in the liver and to study its possible consequences.

\section{Materials and Methods}

\section{Animals}

Male Wistar rats (Jautz, Kisslegg, FRG) weighing between 130 and $170 \mathrm{~g}$ were used. The animals were on a commercial diet (Altromin, Altromin GmbH, Lage-Lippe, FRG), water was given ad libitum. The rats were deprived of food overnight before each experiment.

\section{Chemicals and Insulin Preparations}

D-galactosamine hydrochloride (puriss.) was purchased from C. Roth (Karlsruhe, FRG). Adenosine 5'-monophosphate disodium salt, adenosine $5^{\prime}$-triphosphate disodium salt and glucose6-phosphate were from Beohringer Mannheim (Mannheim, FRG), p-nitrophenylthymidine $5^{\prime}$-monophosphate was from Sigma Chemicals Co. (St. Louis, Mo., USA) and human albumin from the Swiss Red Cross (Berne, Switzerland). Streptozotocin- 
Table 1. Blood glucose, plasma insulin, plasma aspartate aminotransferase, and specific insulin binding to liver plasma membranes after D-galactosamine treatment. Insulin binding was performed with plasma membranes prepared from 4 livers; the number of preparations are given in brackets. Specific binding was determined at $4 \mathrm{ng} / \mathrm{ml}$ of insulin. Values represent the mean \pm SEM. Statistical significance in comparison to control is indicated under each value

\begin{tabular}{|c|c|c|c|c|c|c|c|}
\hline $\begin{array}{l}\text { Animal } \\
\text { preparation }\end{array}$ & $\begin{array}{l}\text { Time after } \\
\text { galactosamine } \\
\text { injection }\end{array}$ & $\begin{array}{l}\text { No. of } \\
\text { animals }\end{array}$ & $\begin{array}{l}\text { Blood } \\
\text { glucose }\end{array}$ & $\begin{array}{l}\text { Plasma insulin } \\
\mu \mathrm{U} / \mathrm{ml}\end{array}$ & $\begin{array}{l}\text { Specific } \\
\text { insulin } \\
\text { binding } \\
\mathrm{ng} / \mathrm{mg}\end{array}$ & $\begin{array}{l}\text { Plasma aspartate } \\
\text { aminotransferase } \\
\mathrm{mU} / \mathrm{ml}\end{array}$ & Body weight \\
\hline \multirow{5}{*}{$\begin{array}{l}\text { Control } \\
\text { D-galactos- } \\
\text { amine }\end{array}$} & 0 & 34 & $4.6 \pm 0.2$ & $10.5 \pm 1.1$ & $0.99 \pm 0.05(10)$ & $31 \pm 2$ & $132 \pm 3$ \\
\hline & 3 & 16 & $\begin{array}{l}3.7 \pm 0.2 \\
p<0.02\end{array}$ & $\begin{array}{r}6.5 \pm 1.5 \\
p<0.05\end{array}$ & $\begin{array}{l}0.42 \pm 0.08(4) \\
\mathrm{p}<0.001\end{array}$ & $47 \pm 3$ & $138 \pm 5$ \\
\hline & 6 & 18 & $\begin{array}{c}4.2 \pm 0.1 \\
\text { NS }\end{array}$ & $\begin{array}{l}53.1 \pm 10.8 \\
p<0.001\end{array}$ & $\begin{array}{l}0.47 \pm 0.05(6) \\
p<0.001\end{array}$ & $84 \pm 8$ & $159 \pm 5$ \\
\hline & 12 & 18 & $\begin{array}{c}4.3 \pm 0.3 \\
\mathrm{NS}\end{array}$ & $\begin{array}{l}49.0 \pm 11.5 \\
p<0.001\end{array}$ & $\begin{array}{l}0.40 \pm 0.06(5) \\
p<0.001\end{array}$ & $96 \pm 8$ & $134 \pm 4$ \\
\hline & 24 & 18 & $\begin{array}{c}4.1 \pm 0.2 \\
\mathrm{NS}\end{array}$ & $\begin{array}{l}21.5 \pm 7.1 \\
p<0.001\end{array}$ & $\begin{array}{l}0.40 \pm 0.03(6) \\
p<0.001\end{array}$ & $176 \pm 31$ & $133 \pm 2$ \\
\hline
\end{tabular}

$\mathrm{HCl}$ was provided by the Upjohn Company (Heppenheim, FRG). All other chemicals were of reagent grade and werc purchased from E. Merck AG (Darmstadt, FRG) and Serva (Heidelberg, FRG). Beef monocomponent [ ${ }^{125} \mathrm{I}$-labelled insulin (sp. act. 29 $\mathrm{Ci} / \mathrm{g})$, unlabelled monocomponent beef insulin ( $27 \mathrm{units} / \mathrm{mg})$, and rat standard insulin were generous gifts from NOVO Company (Copenhagen, Denmark).

\section{Experimental Procedures}

Animal Treatment: In order to induce hepatitis the rats received a single IP injection of $400 \mathrm{mg} / \mathrm{kg}$ of D-galactosamine- $\mathrm{HCl} 3,6,12$ or $24 \mathrm{~h}$ before the liver was removed. Diabetes was induced by IV administration of $100 \mathrm{mg}$ of streptozotocin- $\mathrm{HCl}$ (dissolved in $0.154 \mathrm{~mol} / 1 \mathrm{NaCl}, \mathrm{pH} 4.0$ ) per $\mathrm{kg}$ body wt. 6 days before the animals were killed. Control groups were injected with identical volumes of $0.154 \mathrm{~mol} / 1 \mathrm{NaCl}$-solution IP or IV, respectively. Blood samples were obtained from anaesthetized rats $(10 \mathrm{mg}$ Nembutal intraperitoneally) by aortic or portal vein puncturc. Blood glucose was determined by the hexokinase method [16], plasma aspartate aminotransferase according to Bergmeyer [17], plasma immunoreactive insulin was measured by the Herbert modification [18] of the Yalow-Berson radioimmunoassay [19] using a rat insulin standard.

Intravenous Glucose Tolerance Test: IV glucose tolerance test was performed after a fasting period of $24 \mathrm{~h}$. Rats were anaesthetized and $0.5 \mathrm{~g} / \mathrm{rat}$ of glucose was given as a $50 \%$ solution via a superficial jugular vein within $30 \mathrm{sec}$. Venous (tail vein) blood samples were taken at various intervals between -5 and 180 min for glucose determination.

Plasma Menbrane Isolation: Liver plasma membranes were isolated by a modification of the methods of Neville [20] and Ray [21] as described before [10]. Four livers were pooled for one membrane preparation. The purity of the plasma membrane fractions was checked by electron microscopy and by several enzyme markers for plasma membrane (5'-nucleotidase [22], $\mathrm{Na}^{+}+\mathrm{K}^{-}-$ ATPase [23], alkaline phosphatase [24]), mitochondria (succinate dchydrogenase [25]) and endoplasmatic reticulum (glucose-6phosphatase [26]). Protein was determined by the method of I.owry et al. [27] with bovine serum albumin as a standard.
Binding Studies: The method employed in the binding studies has becn described in detail [28]. In brief, insulin binding to rat liver plasma membranes was performed in duplicate samples at $25^{\circ} \mathrm{C}$, containing $40 \mathrm{mmol} / 1$ Tris- $\mathrm{HCl}$ buffer, $\mathrm{pH} 7.4,20 \mathrm{mg} / \mathrm{ml}$ of human serum albumin, $2 \mathrm{ng}$ of $\left.{ }^{125} \mathrm{I}\right]$-insulin, unlabelled insulin at various concentrations from 0 to $40 \mu \mathrm{g} / \mathrm{ml}$, and plasma membrancs corresponding to $40-480 \mu \mathrm{g}$ protein, in a volume of $500 \mu \mathrm{l}$. The reaction was started by addition of the plasma membranes. Except when stated otherwise, membranes were incubated for $120 \mathrm{~min}$ whilc gently shaken. The incubation was terminated by centrifugation through silicone oil. All data are reported as specific binding, i. c. after subtraction of nonspecific binding as determined in the presence of $40 \mu \mathrm{g} / \mathrm{ml}$ of insulin $(5-10 \%$ of total).

Electron Microscopy: Plasma membrane fractions were fixed in $3 \%$ glutaraldehyde followed by $1 \%$ osmium tetroxide, both in phosphate buffered solution at $\mathrm{pH}$ 7.4. Pellets were dehydrated in a graded series of ethanol and embedded in cpon. Thin sections were stained with lead citrate and examined in an Elmiskop 101 E. M. (Siemens).

Results are presented as mean $\doteq$ SEM. Statistical analysis of the differences between control, diabetic and D-galactosaminetreated groups was performed using Student's t-test.

\section{Results}

\section{Plasma Aspartate Aminotransferase} and Light Microscopic Features of the Liver after D-Galactosamine Administration

The continuous increase in the activity of aspartate aminotransferase from 3 to $24 \mathrm{~h}$ after the injection of D-galactosamine indicates the development of mild hepatitis (Table 1). By light microscopy minimal morphological change with Councilman bodies and atypical dense bodies in parenchymal liver cells, single cell necroses, and inflammatory cells were seen not sooner than $6 \mathrm{~h}$ after the injection of D-galactosamine. The number of single cell necroses and 
Table 2. Blood glucose after intravenous glucose $(0.5 \mathrm{~g} /$ rat $)$ in D-galactosamine-treated and control rats. Both groups were starved for $24 \mathrm{~h}$. Concentration of blood glucose was expressed in $\mathrm{mmol} / \mathrm{l}$ whole blood, as mean values $\pm \mathrm{SEM}$

\begin{tabular}{|c|c|c|c|c|c|}
\hline \multirow[b]{2}{*}{ Minutes } & \multirow{2}{*}{$\begin{array}{l}\text { Control } \\
(\mathrm{n}=6)\end{array}$} & \multicolumn{4}{|c|}{ Time after D-galactosamine injection } \\
\hline & & $6 \mathrm{~h}(\mathrm{n}=6)$ & $\begin{array}{l}\text { Significance } \\
\text { vs. control }\end{array}$ & $12 \mathrm{~h}(\mathrm{n}=6)$ & $\begin{array}{l}\text { Significance } \\
\text { vs. control }\end{array}$ \\
\hline-5 & $4.9 \pm 0.4$ & $3.7 \pm 0.2$ & $<0.02$ & $3.6 \pm 0.1$ & $<0.005$ \\
\hline 0 & $4.9 \pm 0.2$ & $3.7 \pm 0.1$ & $<0.005$ & $3.8 \pm 0.1$ & $<0.005$ \\
\hline 2 & $31.6 \pm 2.9$ & $36.0 \pm 0.9$ & NS & $35.5 \pm 1.8$ & NS \\
\hline 5 & $35.2 \pm 1.8$ & $36.7 \pm 0.8$ & NS & $37.0 \pm 1.0$ & NS \\
\hline 10 & $33.7 \pm 1.6$ & $34.6 \pm 1.1$ & NS & $34.7 \pm 1.1$ & NS \\
\hline 15 & $30.3 \pm 1.3$ & $31.5 \pm 0.8$ & NS & $31.3 \pm 0.9$ & NS \\
\hline 30 & $24.2 \pm 1.0$ & $26.7 \pm 0.9$ & NS & $27.3 \pm 0.9$ & $<0.05$ \\
\hline 45 & $19.1 \pm 1.3$ & $21.6 \pm 0.5$ & NS & $24.0 \pm 0.6$ & $<0.01$ \\
\hline 60 & $15.7 \pm 1.5$ & $18.2 \pm 0.4$ & NS & $22.4 \pm 0.9$ & $<0.005$ \\
\hline 90 & $10.3 \pm 1.4$ & $14.5 \pm 1.2$ & NS & $18.8 \pm 0.7$ & $<0.001$ \\
\hline 120 & $7.5 \pm 0.8$ & $10.9 \pm 1.4$ & NS & $14.8 \pm 1.2$ & $<0.001$ \\
\hline 150 & $6.4 \pm 0.4$ & $7.8 \pm 0.5$ & NS & $12.0 \pm 1.0$ & $<0.001$ \\
\hline 180 & $5.9 \pm 0.3$ & $6.8 \pm 0.5$ & NS & $10.1 \pm 0.9$ & $<0.005$ \\
\hline
\end{tabular}

inflammatory cells increased slightly up to $24 \mathrm{~h}$. Cell necrosis was observed in less than one percent of parenchymal cells at $24 \mathrm{~h}$.

Fasting Blood Glucose, Fasting Plasma Insulin and Intravenous Glucose Tolerance Test in D-Galactosamine-Treated Rats

After an overnight fast and $3 \mathrm{~h}$ after the administration of $\mathrm{D}$-galactosamine the blood glucose level was decreased and the plasma insulin concentration was slightly diminished (Table 1). 6 and $12 \mathrm{~h}$ following D-galactosamine, however, the plasma insulin level was elevated about 5-fold, a two-fold increase still remaining after $24 \mathrm{~h}$. Portal insulin levels were measured in a control group, and $12 \mathrm{~h}$ after galactosamine administration. They were $45 \pm 7.8 \mu \mathrm{U} / \mathrm{ml}$ for controls $(\mathrm{n}=8)$, and $215 \pm 36$ in galactosaminetreated rats $(\mathrm{n}=8)$. In $24 \mathrm{~h}$ starved rats blood glucose was also decreased 6 and $12 \mathrm{~h}$ after D-galactosamine injection (Table 2). While 6 hours after Dgalactosamine administration no significant change in glucose tolerance could be detected, a slower fall was evident after $12 \mathrm{~h}$ with significant differences between 30 and 180 min following IV glucose administration (Table 2).

\section{Characteristics of Hepatic Plasma Membranes from $D$-Galactosamine-Treated Rats}

As shown in Table 3, the liver plasma membrane fractions of control and D-galactosamine-treated rats were comparable in the pattern of marker enzymes for plasma membranes (5'-nucleotidase, alkaline phosphatase, $\left(\mathrm{Na}^{+}+\mathrm{K}^{+}\right)$-ATPase), mitochondria (succinate dehydrogenase), and endoplasmatic reticulum (glucose-6-phosphatase). In addition, electron microscopic examination of the various plasma membrane fractions showed no evidence for significant organelle contamination (Fig. 1). The yield of plasma membranes measured as $\mathrm{mg}$ of protein per $\mathrm{g}$ wet wt. of liver was $0.67 \pm 0.10 \mathrm{mg}$ in controls, 0.61 $\pm 0.12 \mathrm{mg} 3 \mathrm{~h}, 0.60 \pm 0.07 \mathrm{mg} 6 \mathrm{~h}, 0.98 \pm 0.08 \mathrm{mg}$ $12 \mathrm{~h}$, and $0.76 \pm 0.22 \mathrm{mg} 24 \mathrm{~h}$ after D-galactosamine administration.

\section{Insulin Binding in D-Galactosamine-Treated Rats}

At $25^{\circ} \mathrm{C}$ the specific binding of $\left[{ }^{125} \mathrm{I}\right]$-insulin to liver plasma membranes of normal and D-galactosaminetreated rats was rapid: The binding reached a maximum at $60 \mathrm{~min}$ (Fig. 2) and remained unchanged up to $6 \mathrm{~h}$. If the binding was expressed as ng per $\mathrm{mg}$ of membrane protein, the specific binding of $\left[{ }^{125} \mathrm{I}\right]$-insulin to plasma membranes of $\mathrm{D}$-galactosamine-treated rats was about $50 \%$ lower throughout the entire time course. The time course of association of $\left[{ }^{125} \mathrm{~T}\right]$-insulin to liver plasma membranes of D-galactosaminetreated and control animals was identical when maximal binding was set at $100 \%$.

When bound insulin was plotted as a function of hormone concentration, insulin binding in D-galactosamine-treated animals was proportionally decreased to $40-60 \%$ in comparison to that of control animals over the range of 0.4 to $800 \mathrm{ng}$ insulin per $\mathrm{ml}$ (Fig. 3A). The greatest reduction in specific insulin binding to liver plasma membranes in Dgalactosamine-treated rats was seen after $12 \mathrm{~h}$. The Scatchard plot [29] shows a parallel shift, which indicates a decrease in receptor concentration after galactosamine treatment (Fig. 3B). 
Table 3. Comparison of enzyme activities in homogenates and plasma membrane fractions from untreated and D-galactosamine-treated rat livers. $\mathrm{H}$, homogenate; PM, plasma membrane; RSA, relative specific activity. For each plasma membrane preparation, four livers were combined. Results are the means \pm SEM for the numbers of experiments given in parenthesis

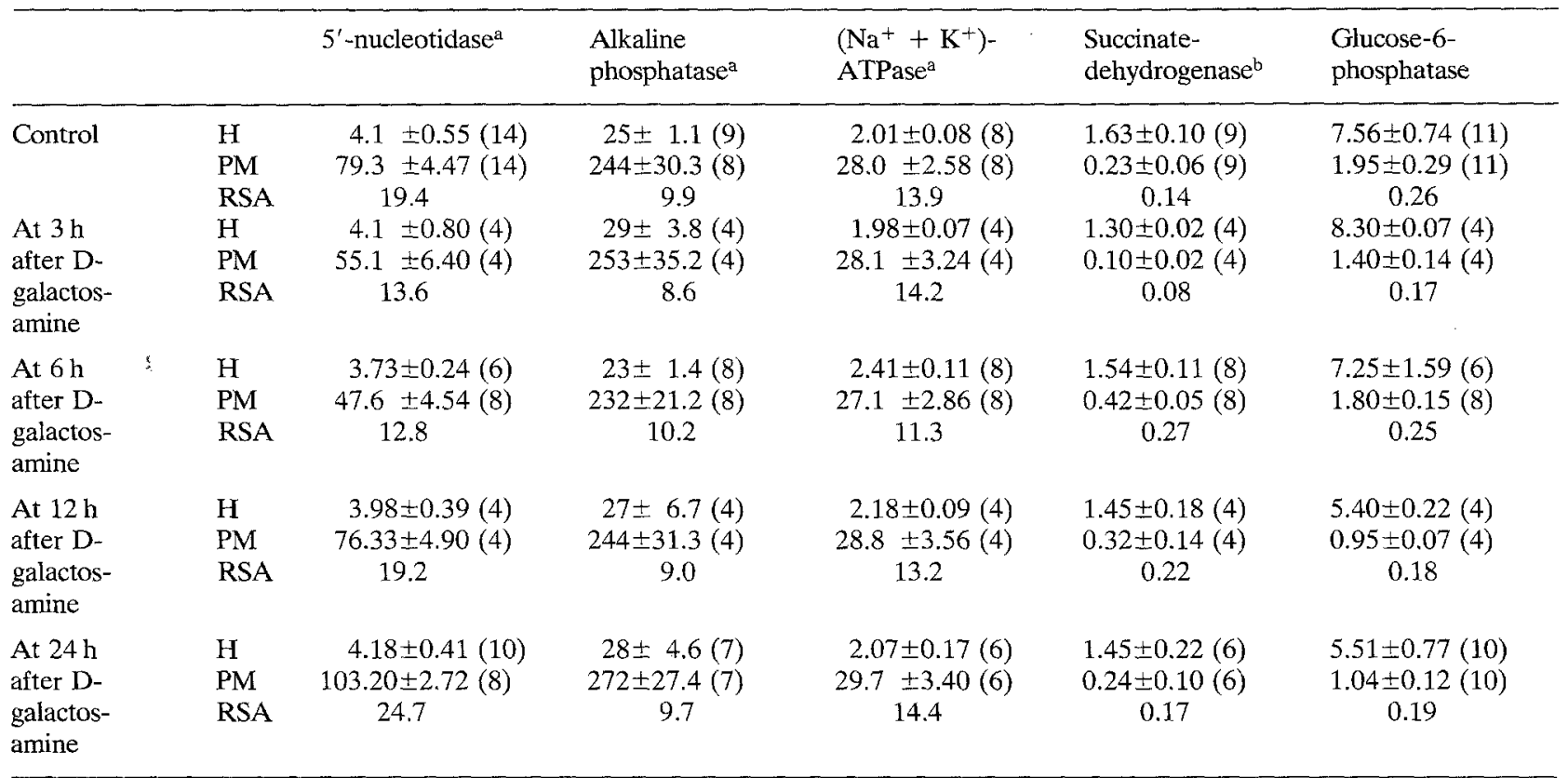

a $\mu \mathrm{mol}$ of phosphate liberated $/ \mathrm{h}$ per $\mathrm{mg}$ of protein at $37^{\circ} \mathrm{C}$

b $\mathrm{nmol}$ of 2 -(p-iodophenyl)-3-(p-nitrophenyl) -5-phenyltetrazolium reduced/h per $\mathrm{mg}$ of protein at $37^{\circ} \mathrm{C}$

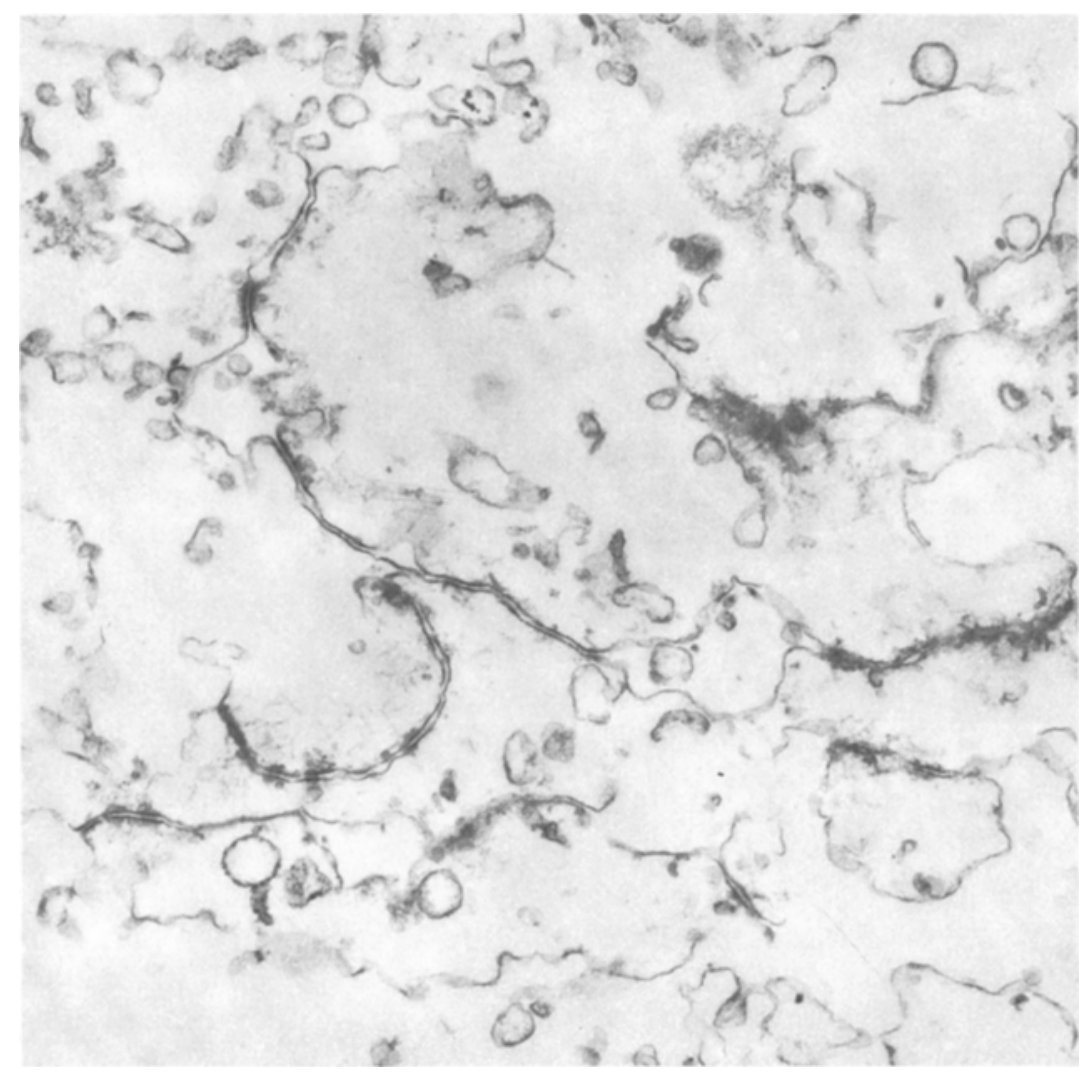

Fig. 1. Electron micrograph of a liver plasma membrane fraction $12 \mathrm{~h}$ after $\mathrm{D}$-galactosamine injection. $\times 30,000$ 


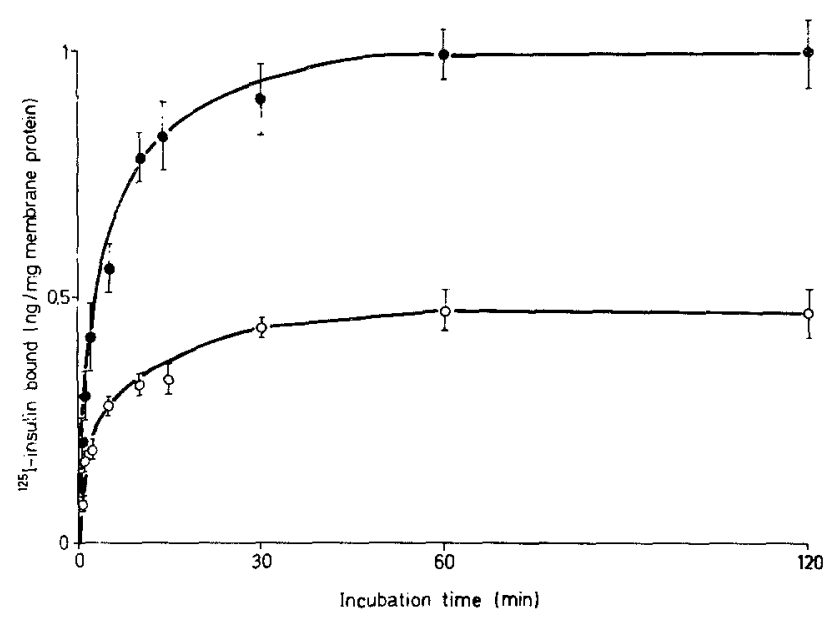

Fig. 2. Time course of binding ${ }^{125} I 7-$ insulin to liver plasma membranes of control and D-galactosamine-treated rats $(12 \mathrm{~h}$ after the injection). $2 \mathrm{ng}$ of $\left[{ }^{125} \mathrm{I}\right]$-insulin were incubated with membranes $(0.2 \mathrm{mg}$ protein $/ \mathrm{ml})$ in the absence and in the presence of $40 \mu \mathrm{g} / \mathrm{ml}$ of unlabelied insulin. At zero time the membranes were added and at varying times samples were removed and processed as indicated under "Materials and Methods". The binding is expressed as specifically bound $\left[{ }^{125} \mathrm{I}\right]$-insulin. Values are means \pm SEM, --.--control $(n=9), 0---O$ D-galactosamine $(n=5)$
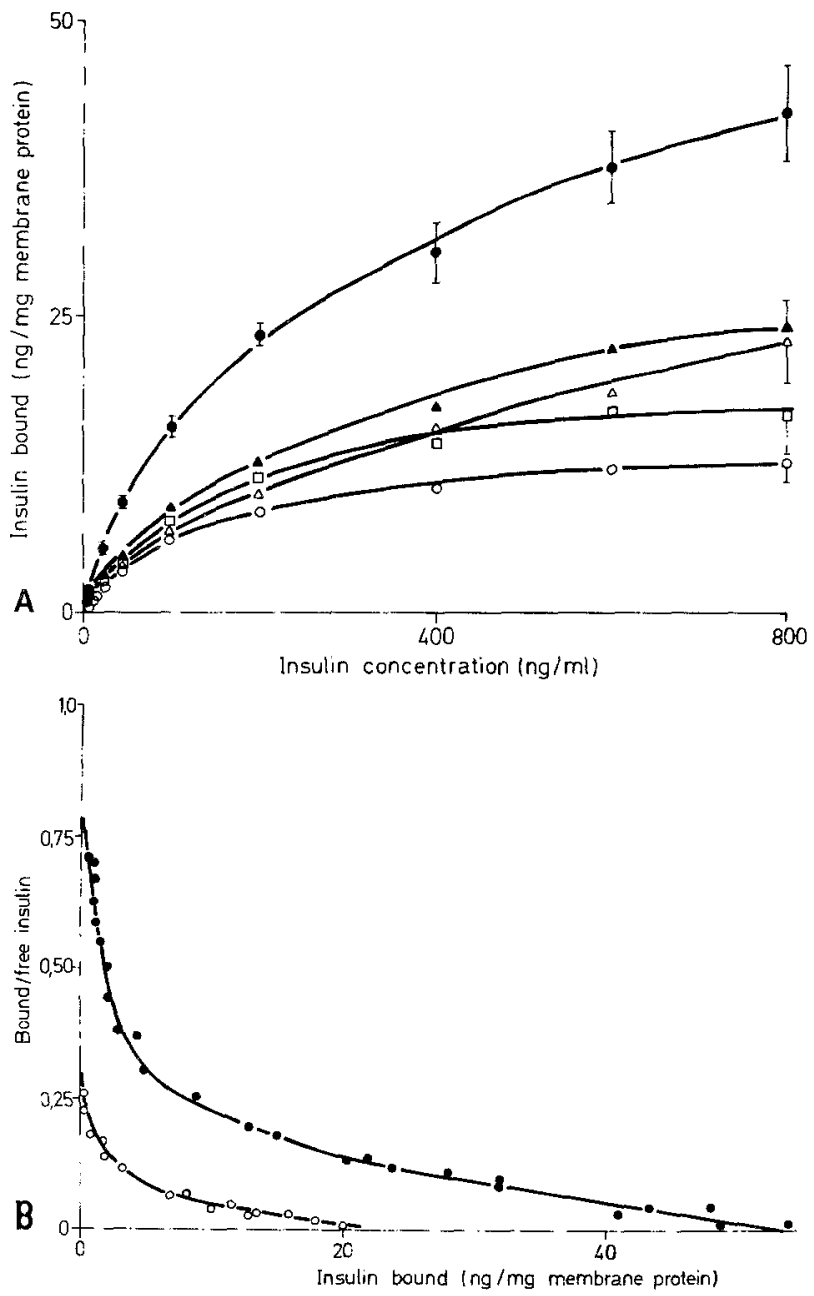

A linear correlation of specific and non-specific binding to plasma membrane concentration $(20 \mu \mathrm{g}$ to $480 \mu \mathrm{g}$ of membrane protein) was evident for all membrane preparations used (Fig. 4).

The insulin-degrading activities of the plasma membrane fractions were determined by measuring the formation of radioactive products soluble in $0.6 \mathrm{~mol} / 1$ trichloroacetic acid from [ $\left.{ }^{125} \mathrm{I}\right]$-labelled insulin. In all groups $\left[{ }^{125} \mathrm{I}\right]$-insulin degradation by hepatic plasma membranes was between 0.005 and $0.086 \%$ of total radioactivity; no significant difference could be seen between control and D-galactosamine-treated groups.

Studies on the dissociation of hormone-receptor complexes were performed by preincubating the membranes in the presence of $2 \mathrm{ng}\left[{ }^{125} \mathrm{I}\right]$-insulin followed by the addition of $20 \mathrm{ug}$ of unlabelled insulin. Further incubation for 120 min resulted in identical dissociation kinetics in control and D-galactosaminetreated animals (Fig. 5).

\section{Insulin, Glucose and Aspartate Aminotransferase in the Diabetic Rat $12 \mathrm{~h}$ after D-Galactosamine Administration}

In diabetic rats (Tabic 4) D-galactosamine induced a greater increase in aspartate aminotransferase activity as compared to normal rats (Table 1). Fasting blood glucose was increased to $18.8 \mathrm{mmol} / 1$ in diabetic rats with no change after administration of $D$ galactosamine. Plasma insulin concentration in diabetic rats remained low after the injection of Dgalactosamine.
Fig. 3. A Insulin binding to liver plasma membranes of normal and D-galactosamine-treated rats as a function of insulin concentration. Membranes $(0.2 \mathrm{mg} / \mathrm{ml})$ werc incubated for $120 \mathrm{~min}$ at $25^{\circ} \mathrm{C}$ with the indicated amounts of insulin. Specific binding was determined as described in "Materials and Methods". Data for control rats and final points of D-galactosamine groups are the means \pm SEM. Because of clarity of presentations all other results of $\mathrm{D}$-galactosamine-treated animals were expressed only as means. control $(\mathrm{n}=10), \Delta \cdots \wedge 3 \mathrm{~h}(\mathrm{n}=4), \boldsymbol{\Delta} \cdots \mathbf{\Delta} \mathrm{h}(\mathrm{n}=6)$, - $12 \mathrm{~h}(\mathrm{n}=5)$, and [:-..--! $24 \mathrm{~h}$ after D-galactosamine $(\mathrm{n}=6)$. B Scatchard analysis of receptor-insulin interaction in $D$-galactosamine-treated (12 $\mathrm{h}$ after the injection) and control rats. The concentration of both types of membranes was approx. $0.2 \mathrm{mg} / \mathrm{ml}$, the insulin concentration varied between $0.4 \mathrm{ng}$ and $40 \mu \mathrm{g} / \mathrm{ml}$. Specific binding was detcrmined as described in "Materials and Methods". The bound/free of insulin is plotted as a function of the bound insulin; both axes were normalised to a membrane protein concentration of $1 \mathrm{mg}$ per ml. Each point represents an individual value from 3 experiments. ○---.-o D-galactosamine 
Table 4. Blood glucose, plasma insulin, plasma aspartate aminotransferase, and specific insulin binding to liver plasma membranes in diabetic rats after D-galactosamine treatment. Insulin binding was performed with plasma membranes prepared from 4 livers. The number of preparations are given in brackets. Specific binding was determined at $4 \mathrm{ng} / \mathrm{ml}$ of insulin. Values present the mean \pm SEM. Statistical significance in comparison to control is indicated under each value

\begin{tabular}{|c|c|c|c|c|c|c|c|}
\hline $\begin{array}{l}\text { Animal } \\
\text { preparation }\end{array}$ & $\begin{array}{l}\text { No. of } \\
\text { animals }\end{array}$ & $\begin{array}{l}\text { Blood glucose } \\
\mathrm{mmol} / 1\end{array}$ & $\begin{array}{l}\text { Plasma IRI } \\
\mu \mathrm{U} / \mathrm{ml}\end{array}$ & $\begin{array}{l}\text { Specific } \\
\text { insulin } \\
\text { binding } \\
\mathrm{ng} / \mathrm{mg}\end{array}$ & $\begin{array}{l}\text { Plasma aspartate } \\
\text { aminotransferase } \\
\mathrm{mU} / \mathrm{ml}\end{array}$ & \multicolumn{2}{|c|}{$\begin{array}{l}\text { Body weight } \\
\text { before after } \\
\text { streptozotocin- } \\
\text { injection } \\
\mathrm{g}\end{array}$} \\
\hline Diabetic & 25 & $\begin{array}{l}18.8 \pm 0.7 \\
\text { NS }\end{array}$ & $\begin{array}{c}3.8 \pm 0.6 \\
\mathrm{NS}\end{array}$ & $\begin{array}{l}1.32 \pm 0.07(6) \\
p<0.001\end{array}$ & $\begin{array}{c}45 \pm 5 \\
p<0.01\end{array}$ & $149 \pm 3$ & $125 \pm 3$ \\
\hline $\begin{array}{l}\text { Diabetic } \\
+12 \mathrm{~h} \\
\text { after D- } \\
\text { galactos- } \\
\text { amine in- } \\
\text { jection }\end{array}$ & 12 & $17.2 \pm 0.8$ & $4.3 \pm 0.5$ & $0.81 \pm 0.06$ & $190 \pm 20$ & $153 \pm 2$ & $144 \pm 7$ \\
\hline
\end{tabular}

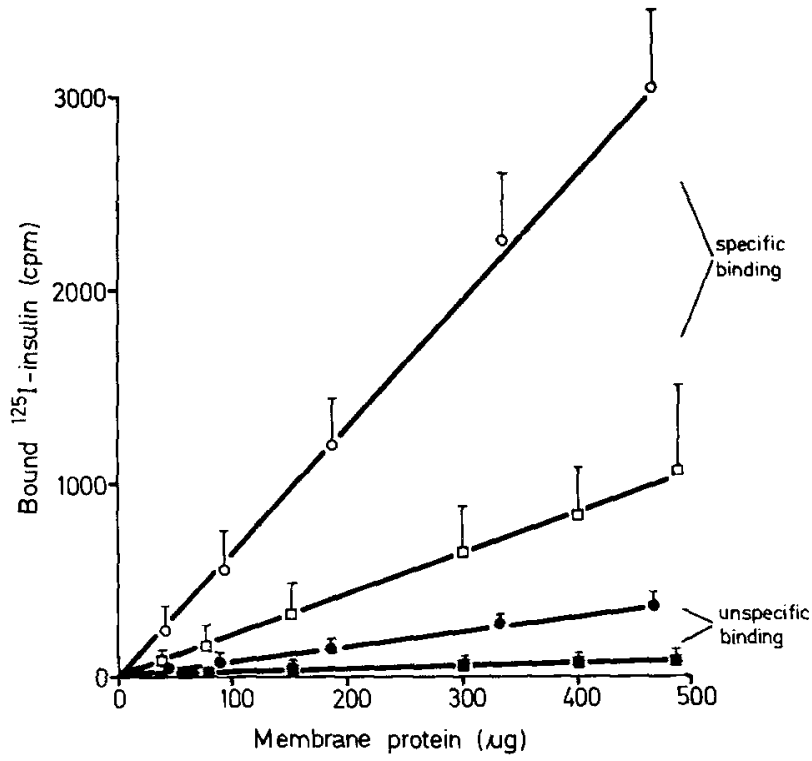

Fig. 4. Specific and non-specific insulin binding as a function of plasma membrane protein in control and D-galactosamine-treated rats. 80 to $960 \mu \mathrm{g} / \mathrm{ml}$ of membrane proteins were incubated for $120 \mathrm{~min}$ at $25^{\circ} \mathrm{C}$ with $2 \mathrm{ng}$ of $\left[{ }^{125} \mathrm{I}\right]$-insulin in the absence and presence of $40 \mu \mathrm{g} / \mathrm{ml}$ of unlabelled insulin. Specific and nonspecific binding were determined as described in "Materials and Methods". Data are expressed as means \pm SEM of 4 membrane

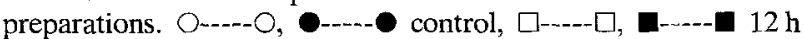
after D-galactosamine

\section{Characteristics of Hepatic Plasma Membranes from Diabetic Rats with and without D-Galactosamine Treatment}

With respect to the activities of marker enzymes the membrane fractions isolated from diabetic rats with and without $\mathrm{D}$-galactosamine-injection were of similar purity and comparable to those from control rats

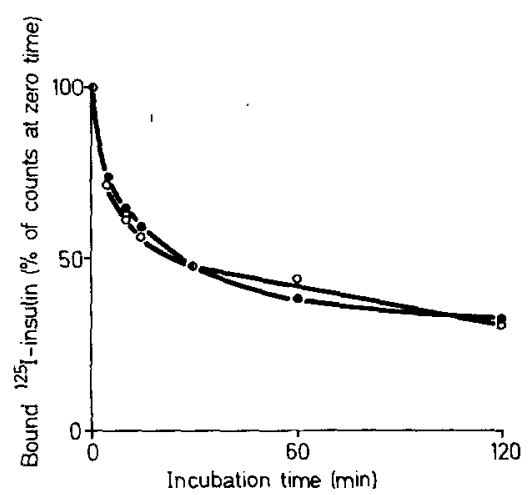

Fig. 5. Dissociation of [225I]-insulin-receptor complex of rat liver plasma membranes from control and D-galactosamine-treated rats after addition of unlabelled insulin. $0.1 \mathrm{mg}$ of membrane protein was incubated for $60 \mathrm{~min}$ at $25^{\circ} \mathrm{C}$ with $2 \mathrm{ng}$ of $\left[{ }^{1.25} \mathrm{I}\right.$ ]-insulin. At zero time $20 \mu \mathrm{g}$ of unlabelled insulin was added and at varying times samples were removed and processed as indicated under "Materials and Methods". The binding is expressed as \% of binding at zero time. Values are means of 4 preparations of control (--.-.) and D-galactosamine-treated rats $\left(12 \mathrm{~h}, \mathrm{O}-\mathrm{-}_{--\mathrm{O})}\right.$

(Table 3). No difference could be observed in the activities of succinate dehydrogenase and glucose 6phosphatase. In diabetic rats the specific activity of 5 -nucleotidase of liver plasma membranes was reduced to $51.6 \pm 13.8 \mu \mathrm{mol}$ phosphate liberated $/ \mathrm{h}$ per mg protein at $37^{\circ} \mathrm{C}(\mathrm{n}=11, \mathrm{p}<0.001) .12 \mathrm{~h}$ after D-galactosamine injection a further decrease to $40.5 \pm 0.5(n=6)$ could be seen. In contrast, the 

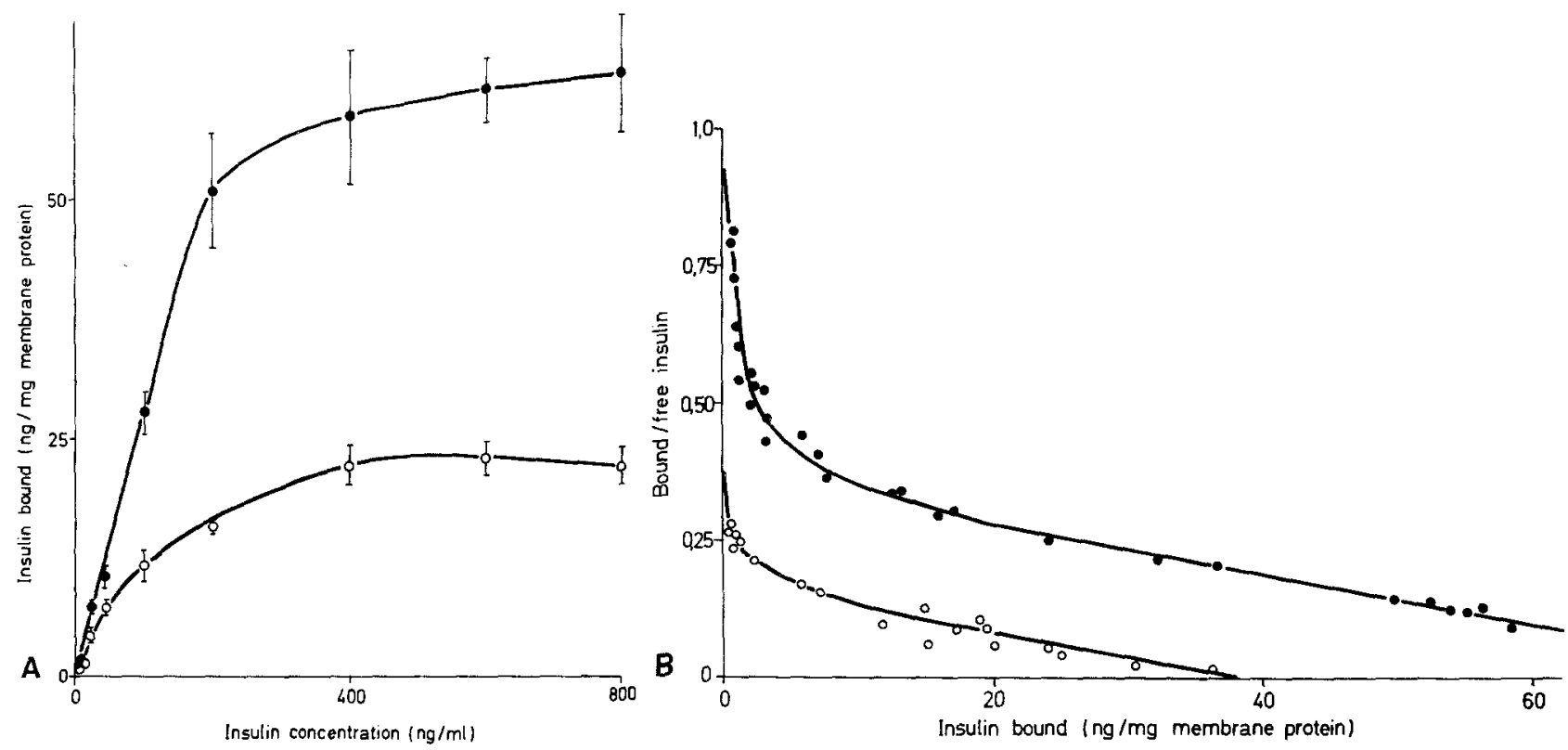

Fig. 6. A Insulin binding to liver plasma membranes of diabetic rats with and without D-galactosamine-treatment as a function of insulin concentration. Membranes (approx. $0.2 \mathrm{mg} / \mathrm{ml}$ ) were incubated for $120 \mathrm{~min}$ at $25^{\circ} \mathrm{C}$ with the indicated amounts of insulin. Specific binding was determined as described in "Materials and Methods". Data are expressed as means \pm SEM. -1 diabetic $(\mathrm{n}=6)$, 0 - - - $\bigcirc 12 \mathrm{~h}$ after D-galactosamine injection in diabetic rats $(\mathrm{n}=4)$. B Scatchard analysis of receptor-insulin interaction in diabetic rats with $(12 \mathrm{~h}$ after the injection) and without D-galactosamine-treatment. The concentration of plasma membranes was approx. $0.2 \mathrm{mg} / \mathrm{ml}$, the insulin concentration varied between $0.4 \mathrm{ng}$ and $40 \mu \mathrm{g} / \mathrm{ml}$. Specific binding was determined as described in "Materials and Methods". The bound/free of insulin is plotted as a function of the bound insulin; both axes were normalised to a membrane protein concentration of $1 \mathrm{mg}$ per ml. Each point represents an individual point from 3 experiments.

diabetic, O--.--O diabetic + D-galactosamine

specific activity of the alkaline phosphatase of the membrane fraction was enhanced to $339 \pm 85$ umol of phosphate liberated/h per $\mathrm{mg}$ protein at $37^{\circ} \mathrm{C}$ $(p<0.05)$ with no change after additional administration of D-galactosamine. These alterations of both plasma membrane marker enzymes in streptozotocin-induced diabetes in rats have been reported before [30]. Again, electron microscopy did not reveal any difference in membrane structure or contamination with other organelles. In diabetic rats the yield of liver plasma membranes was $0.98 \pm 0.22 \mathrm{mg}$ of membrane protein per $\mathrm{g}$ wet wt. and $0.63 \pm$ $0.16 \mathrm{mg}$ at $12 \mathrm{~h}$ after D-galactosamine administration.

\section{Insulin Binding in Diabetic Rats after D-Galactosamine Treatment}

As shown in Fig. 6 the same pronounced decrease in specific insulin binding to membranes $12 \mathrm{~h}$ after the injection of D-galactosamine was observed in diabetic rats. In addition, Scatchard analysis again showed identically shaped curves for diabetic and diabetic rats treated with $\mathrm{D}$-galactosamine.

\section{Discussion}

Insulin resistance is defined as diminished sensitivity of target tissues to endogenous or exogenous insulin. Consequently, the hallmarks of insulin resistance are elevated plasma insulin concentration in the presence of normoglycaemia and/or enhanced insulin demand in insulin-dependent diabetics. In acute virus hepatitis in man increased plasma insulin levels in addition to impaired glucose tolerance have been reported. These results were interpreted as an expression of insulin resistance due to a reduction in functionally normal hepatocytes $[31,32]$.

During the course of D-galactosamine-induced experimental hepatitis a 5 -fold increase in plasma insulin concentration 6 to $12 \mathrm{~h}$ after the injection of the aminosugar could be seen (Table 1). This elevation of plasma insulin together with the development of glucose intolerance (Table 2) suggests insulin resistance. According to light microscopical findings, cellular damage due to galactosamine in other target organs for insulin such as muscle and adipose tissue is unlikely (R. Lesch: personal communication). This points to the selectively affected liver cell as the 
source of insulin resistance. In the liver, extensive cellular necroses could be considered as a major factor. However, at 6-12 hours, where hyperinsulinaemia was already marked, necrosis was found to be negligible. Even at higher doses of galactosamine, a substantial degree of necrosis was observed only at a much later stage of hepatitis ( $>$ $24 \mathrm{~h})[33,34]$. The similar ratio of portal versus peripheral insulin (4.29 vs. 4.39 in control and $12 \mathrm{~h}$ galactosamine-treated, respectively) also argues against extensive liver damage and excludes the possiblity of reduced insulin breakdown as a cause for peripheral hyperinsulinaemia in these animals.

In contrast to the morphological changes, pronounced inhibition of protein and RNA synthesis was already evident at 30-120 min [35]. The metabolic alterations of the liver cell include inhibition of glycoprotein synthesis [11] and distinct changes in protein and phospholipid metabolism of the plasma membrane [10]. These alterations in the composition of essential plasma membrane constituents may well account for the reduction in insulin binding sites observed in D-galactosamine-induced hepatitis. Since the insulin receptor of the liver plasma membrane seems to be a glycoprotein [13-15], its effectiveness might be modulated by phospholipids, as discussed in the case of the effect of phosphatidylinositol upon receptors, which activate adenylate cyclase [36]. According to the time sequence after Dgalactosamine injection, the reduction of the number of insulin binding sites of liver plasma membranes at $3 \mathrm{~h}$ clearly precedes the increase in plasma insulin concentration (Table 1, Fig. 3A) which is elevated at $6 \mathrm{~h}$. In spite of this well-documented sequence of events, additional control studies in streptozotocininduced diabetic rats were performed. Though in diabetic animals no increase in plasma insulin concentration after D-galactosamine administration occurred (Table 4), the binding of [ $\left.{ }^{125} \mathrm{I}\right]$-insulin was also reduced to $40 \%$ of controls.

The present data can not exclude a possible role of hepatic factors which cause peripheral insulin resistance or changes in intermediary metabolism of the liver resulting in hepatic insulin resistance. Of other agents known to cause insulin resistance, glucagon, cortisol and free fatty acids could be excluded since their levels were not significantly different (unpublished results). However, in considering all results presented herein, the most likely explanation is that the reduction in the number of hepatic insulin receptors leads to insulin resistance with a subsequent increase in plasma insulin.

Acknowledgements. We thank Dr. E. A. Siess for electron microscopic and Dr. R. Lesch for light microscopic examinations of the livers and the plasma membrane fractions.
The skillful technical assistance of Mrs. A. Melzer is greatfully acknowledged.

This work has been supported by the Deutsche Forschungsgemeinschaft, Bad Godesberg, Germany.

\section{References}

1. Kahn, C. R., Roth, J.: Insulin receptors in disease states. In: Hormone-receptor interaction: molecular aspects. Levey, G. S. (Ed.), pp. 1-29. New York, Basel: Marcel Dekker, Inc. 1976

2. Freychet, P.: Recent studies on insulin-receptor interactions. Isr. J. Med. Sci. 11, 679-686 (1976)

3. Kahn, C. R., Megyesi, K., Bar, R. S., Eastman, R. C., Flier, J. S.: Receptors for peptide hormones. New insights into the pathophysiology of disease states in man. Ann. Intern. Med. 86, 205-219 (1977)

4. DeFronzo, R. A., Soman, V., Sherwin, R.S., Hendler, R., Felig, Ph.: Insulin binding to monocytes and insulin action in human obesity, starvation, and refeeding. J. Clin. Invest. 62, 204-213 (1978)

5. Hepp, K. D., Langley, J., v. Funcke, J., Renner, R., Kemmler, W.: Increased insulin binding capacity of liver membranes from diabetic Chinese hamsters. Nature 258, 154 (1975)

6. Davidson, M. B., Kaplan, S. A.: Increased insulin binding by hepatic plasma membranes from diabetic rats. J. Clin. Invest. 59, 22-30 (1977)

7. Beck-Nielsen, H., Pedersen, O.: Insulin receptors on mono cytes of young healthy persons correlated with glucose tolerance and insulin sensitivity. Diabetologia 14, 159-163 (1978)

8. Kobayashy, M., Olefsky, J.M.: Effect of experimental hyperinsulinemia on insulin binding and glucose transport in isolated rat adipocytes. Am. J. Physiol. 235, 53-62 (1978)

9. Keppler, D., Lesch, R., Reutter, W., Decker, K.: Experimental hepatitis induced by D-galactosamine. Exp. Mol. Pathol. 9 , 279-290 (1968)

10. Bachmann, W., Harms, E., Hassels, B., Henninger, H., Reutter, W.: Studies on rat liver plasma membrane. Altered protein and phospholipid metabolism after injection of D-galactosamine. Biochem. J. 166, 455-462 (1977)

11. Reutter, W., Keppler, D., Lesch, R., Decker, K.: Zum Glykoproteidstoffwechsel bei der Galaktosamin-induzierten Hepatitis. Verh. Dtsch. Ges. Inn. Med. 75, 363-365 (1969)

12. Record, C. O., Alberti, K. G. M. M.: Glucose tolerance and blood metabolite changes in galactosamine hepatitis and obstructive jaundice in the rat. Eur. J. Clin. Invest. 3, 130-135 (1973)

13. Jacobs, S., Shechter, Y., Bissell, K., Cuatrecasas, P.: Purification and properties of insulin receptors from rat liver membranes. Biochem. Biophys. Res. Commun. 77, 981-988 (1977)

14. Cuatrecasas, P., Illiano, G.: Membrane sialic acid and the mechanism of insulin action in adipose tissue cells: Effects of digestion with neuraminidase. J. Biol. Chem. 246, 4938-4946 (1971)

15. Cuatrecasas, P., Tell, G.P. E.: Insulin-like activity of concanavalin $A$ and wheat germ agglutinin - Direct interaction with insulin receptors. Proc. Natl. Acad. Sci. USA 70, 485-489 (1973)

16. Schmidt, F.: Die enzymatische Bestimmung von Glucose und Fructose nebeneinander. Klin. Wochenschr. 39, 1244-1247 (1961)

17. Bergmeyer, H. U.: Glutamat-Oxalacetat-Transaminase. In: Methoden der enzymatischen Analyse. Bergmeyer, H. U. (Ed.), pp. 769-755. Weinheim/Bergstr.: Verlag Chemie 1974

18. Herbert, V., Lau, K. S., Gottlieb, C. W., Bleicher, S.: Coated charcoal immunoassay of insulin. J. Clin. Endocrinol. 25, 1375-1384 (1965) 
19. Yalow, R. S., Berson, S. A.: Immunoassay of endogenous plasma insulin in man. J. Clin. Invest. 39, 1157-1175 (1960)

20. Neville, D. M.: The isolation of a cell membrane fraction from rat liver. J. Biophys. Biochem. Cytol. 8, 413-422 (1960)

21. Ray, T. K.: A modified method for the isolation of the plasma membrane from rat liver. Biochim. Biophys. Acta 196, 1-9 (1970)

22. Michell, R. H., Hawthorne, F. N.: The site of diphosphoinositide synthesis in the rat liver. Biochem. Biophys. Res. Commun. 21, 333-338 (1965)

23. Emmelot, P., Bos, C. J.: Studies on plasma membranes. III. $\mathrm{Mg}^{2+}$-ATPase $\left(\mathrm{Na}^{+}-\mathrm{K}^{+}-\mathrm{Mg}^{2+}\right)$-ATPase and 5'-nucleotidase activity of plasma membranes isolated from rat liver. Biochim. Biophys. Acta 120, 369-382 (1966)

24. Emmelot, P., Bos, C. J., Benedetti, E. L., Rümke, P.: Studies on plasma membranes. I. Chemical composition and enzyme content of plasma membranes isolated from rat liver. Biochim. Biophys. Acta 90, 126-145 (1964)

25. Pennington, F.: Biochemistry of dystrophic muscle. Mitochondrial succinate-tetrazolium reductase and adenosine triphosphatase. Biochem. J. 80, 649-654 (1961)

26. DeDuve, C., Pressmann, B. C., Gianetto, R., Wattiaux, R., Appelmans, O. O.: Tissue fractionation studies. 6. Intracellular distribution patterns of enzymes in rat liver tissue. Biochem. J. 60, 604-617 (1955)

27. Lowry, O. H., Rosebrough, N. J., Farr, A. L., Randall, R. L.: Protein measurement with the folin phenol reagent. J. Biol. Chem. 193, 265-275 (1951)

28. Kemmler, W., Renner, R., Zynamon, A., Hepp, K. D.: Interaction between insulins and liver membrane receptors of guinea pig, beef and chicken. Biochim. Biophys. Acta 543, 349-356 (1978)
29. Scatchard, G.: The attractions of proteins for small molecules and ions. Ann. N. Y. Acad. Sci. 51, 660-675 (1949)

30. Chandramouli, V., Carter, Jr., J. R.: Cell membrane changes in chronically diabetic rats. Diabetes 24, 257-262 (1975)

31. Kremer, G. J., Atzpodien, W., Jacobi, H., Friederichs, U., Friederichs, M.: Glucose and insulin tolerance studies in viral hepatitis. Inn. Med. 3, 267-276 (1976)

32. Record, C.O., Alberti, K.G.M.M., Williamson, D.H., Wright, R.: Glucose tolerance and metabolic changes in human viral hepatitis. Clin. Sci. Mol. Med. 45, 677-690 (1973)

33. Medline, A., Schaffner, F., Popper, H.: Ultrastructural feaiures in galactosamine-induced hepatitis. Exp. Mol. Pathol. 12, 201-211 (1970)

34. Sabesin, S. M., Koff, R. S.: D-galactosamine hepatotoxicity. IV. Further studies of the pathogenesis of fatty liver. Exp. Mol. Pathol. 24, 424-434 (1976)

35. Shinozuka, H., Farber, J. L., Konishi, Y., Anukarahanonta, T.: D-galactosamine and acute liver cell injury. Fed. Proc. 32, 1516-1526 (1973)

36. Michell, R. H.: Inositol phospholipids and cell surface receptor function. Biochim. Biophys. Acta 415, 81-147 (1975)

Received: October 30, 1978,

and in revised form: April 9, 1979

Dr. W. Bachmann

III. Medizinische Abteilung

Stadtkrankenhaus Schwabing

Kölner Platz 1

D-8000 München 40

Federal Republic of Germany 